\title{
Breast Cancer
}

What you should know 


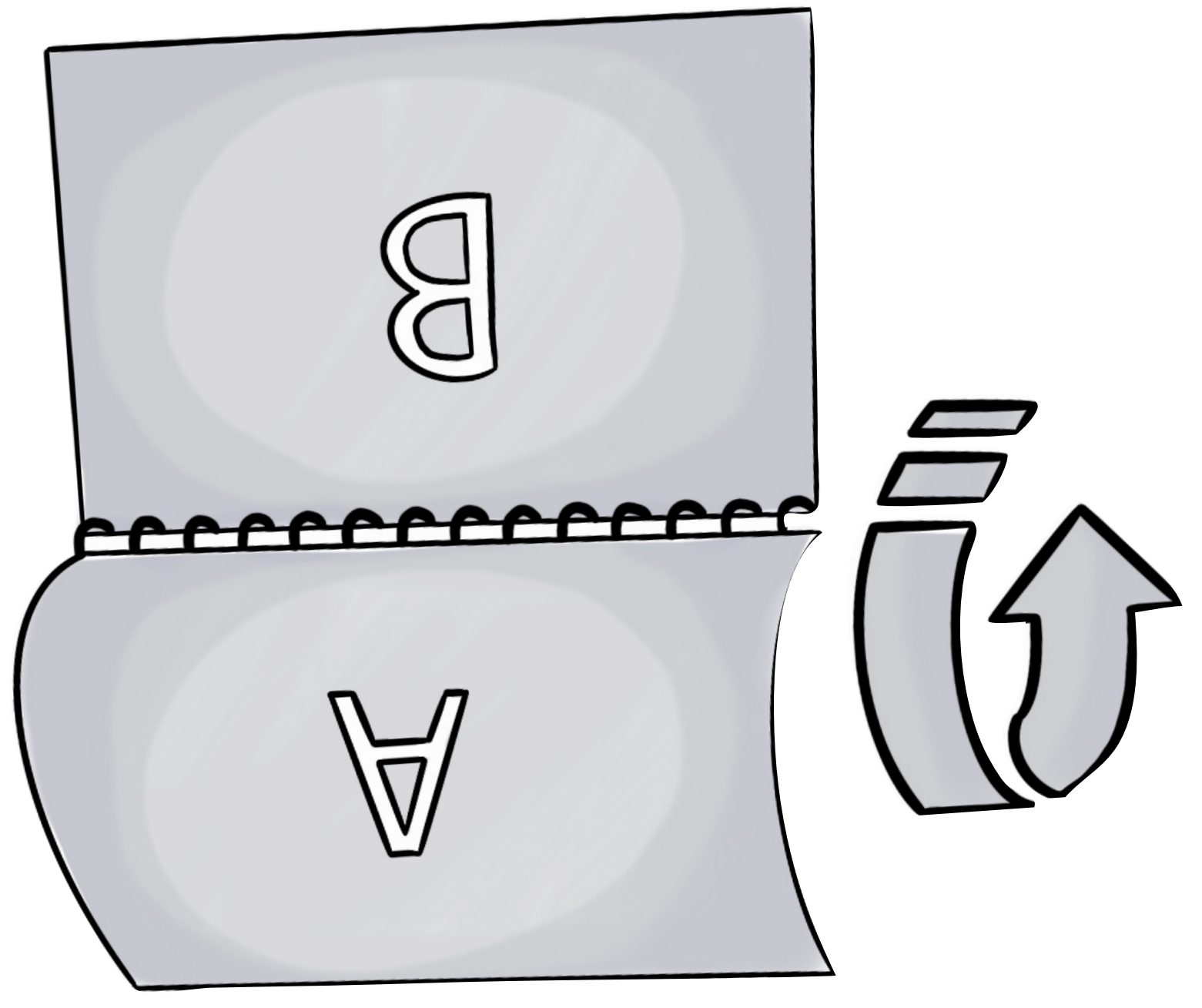

'әz!̣ens!̣ Kem Kł! unumos anok to

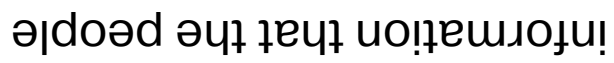
pue sәбem! әцұ su!̣ıนоว

g әp!S

- ио!̣emı⿰丿! әлош 6u!̣!ฺщuо 'jenuew ләоиеว 1seәлg әчұ мә!ләл о Кıеssәวәи S! Il Kł! ol suo!neuejdxə ınok u! әpnјou! pןnous noא łeuł słuәшәрә ग!seq su!ełuoว $\forall$ əp!S

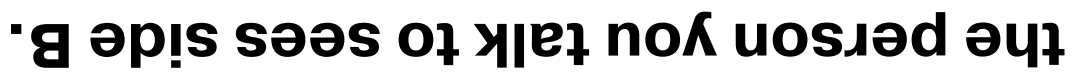

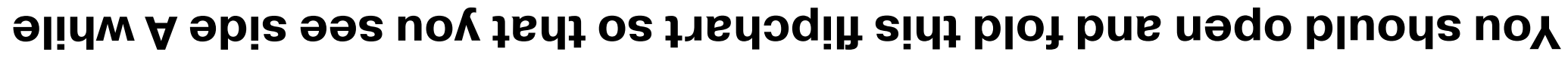




\section{CJSYIVESTER}

UNIVERSITY OF MIAMI HEALTH SYSTEM

This training manual for health promoters was adapted from:

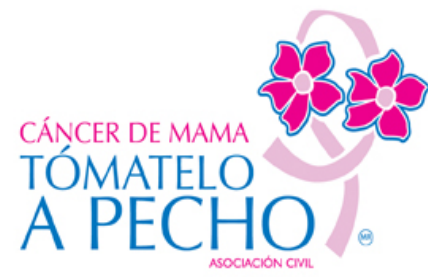

Knaul FM, González Robledo LM, González Robledo MC, Magaña Valladares L. Detección temprana del cáncer de mama. Una tarea de todos. Manual para personal dedicado a la salud de la comunidad. Cuernavaca (MX): Instituto Nacional de Salud Pública (MX); 2010. Coeditado con Tómatelo a Pecho, A.C.

for the context of South Florida, United States and developed by the team of global health researchers of the University of Miami Institute for Advanced Study of the Americas (UMIA):

\section{Natalia Rodriguez, PhD, MPH Principal Investigator}

Felicia Casanova, MA

Graduate Research Assistant

\author{
Julia Olson, MPH \\ Research Associate
}

\section{Felicia Knaul, PhD \\ UMIA Director}

Layla Claure

Research Assistant
Kapriskie Seide, MA, MPH
Graduate Research Assistant

Emily Fakhoury

Graphic Designer
Gabriela Pages

Research Assistant
Marian Pedreira

Research Assistant

With the generous support from:

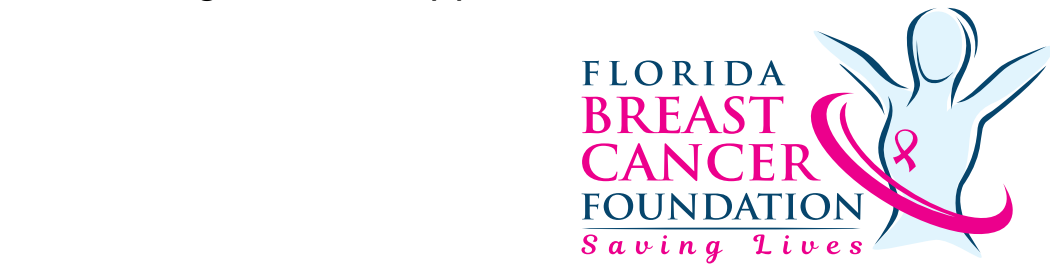

Sofia Mohammad

Graphic Illustrator
Neha Goel, MD

Surgical Oncology Advisor

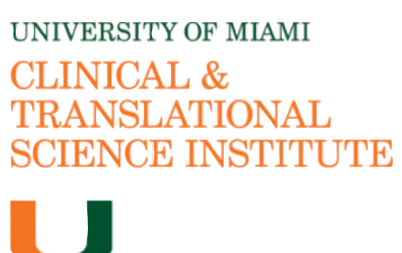

This manual is a work in progress that can be redefined as new data and clinical practice guidelines become available. The authors do not offer any type of guarantee with respect to its content, use or application, and are exempt from any responsibility for its application or use. Last updated August 2019. 
-әред-4ұnos

u! иәшом уәе|q рие иәшом әџ!чм

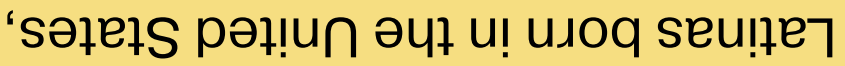

иечұ ио!ґวәјәр ләоиео цо

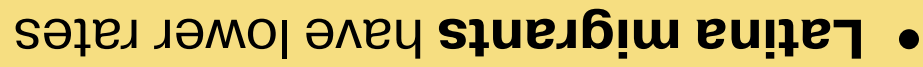

'ләоиео ґsеәля чұ!м pәsou6e!p

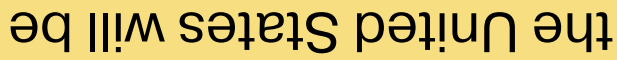

u! uәшом 8 u! เ Кјәјеu!xOıdd $\forall$ • :słoet quełsodu! 6u!no||оł әчł uo!łuәW

ןenuew dəoueว 7seәлg әчң 10 I ләңdечо оғ ләјәу
S||ә0 มәวนеว

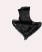

чұеәр ||әэ оu

$\rightarrow$

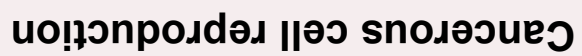

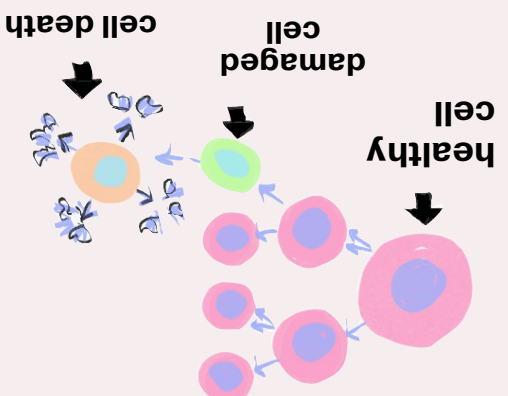

uo!łonposdəג ||ә0 ןeusoN s||ә0 snojəoueo pue ןeunoN

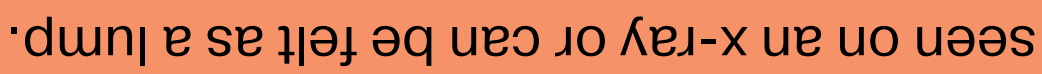

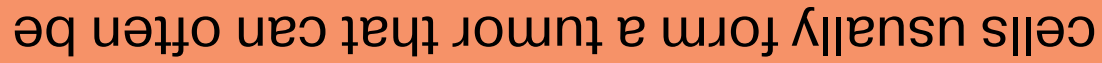

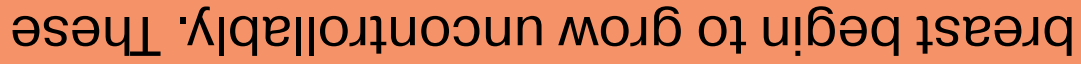

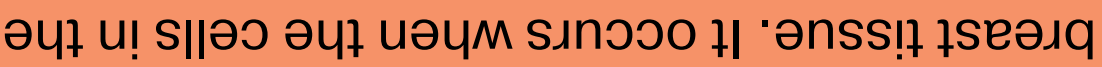

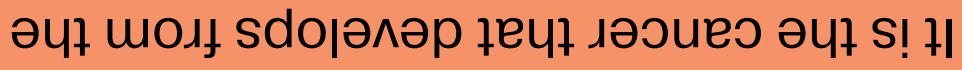

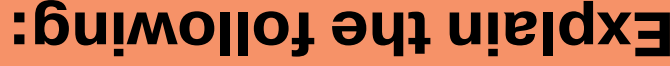

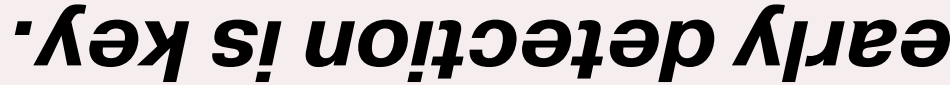

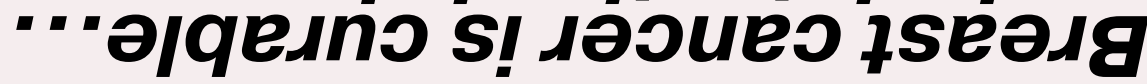

:pu!mod

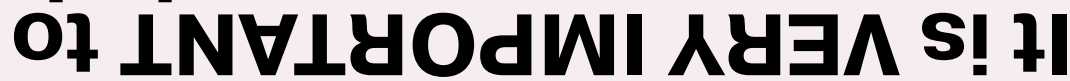

\section{¿dooueo 7seodq S! 7е4M}




\section{What is breast cancer?}

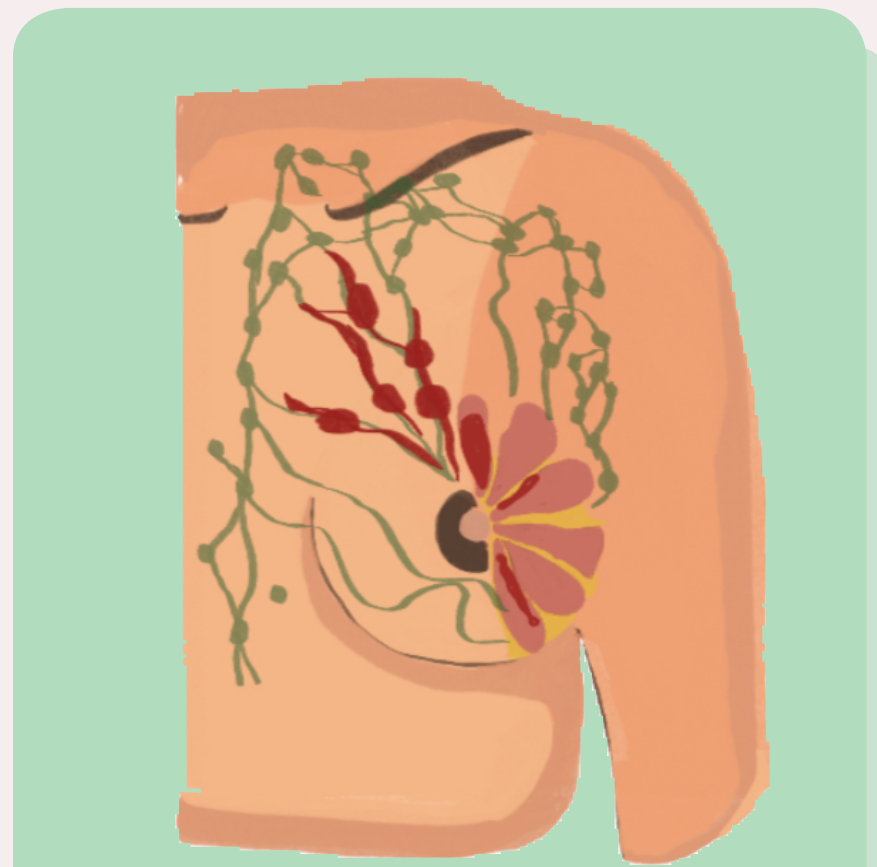

\section{Breast with tumor}

Normal and cancerous cells
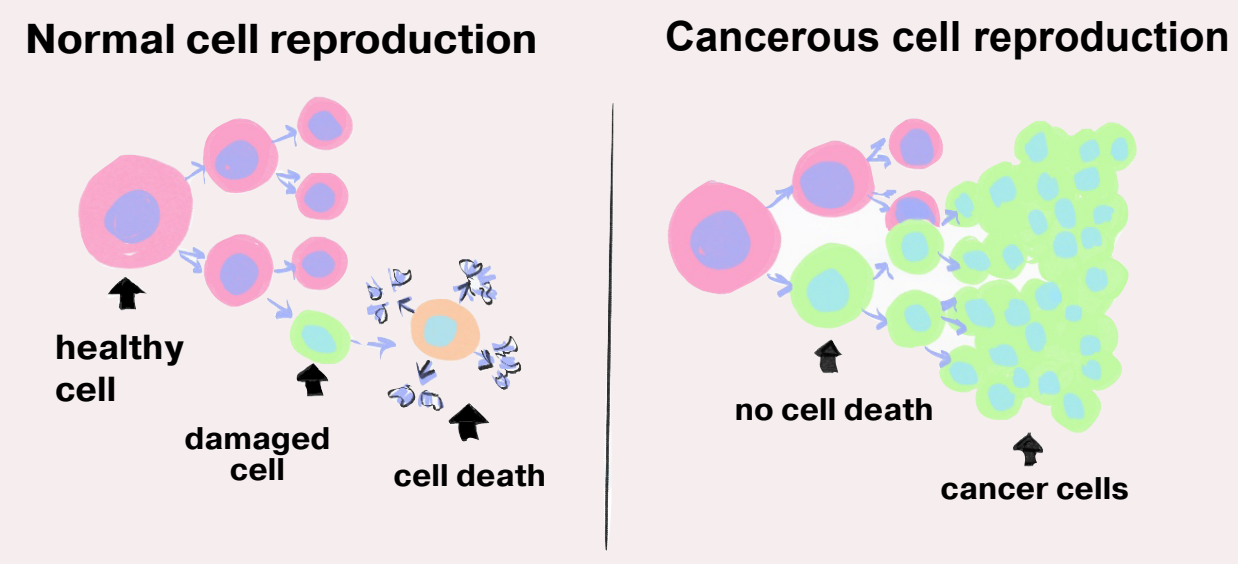

\section{Key Facts}

\section{1 in 8}

women in the United States will be diagnosed with breast cancer.
Breast cancer is curable... early detection is key.

\section{Latina migrants have} lower rates of cancer detection than Latinas born in the United States, white women and black women in South-Dade. 
słseәлq әбле| Кıәл 10 ॥еus

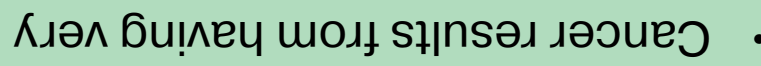
ıәэueo to s!̣soube!p

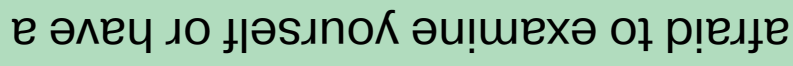
10 pәmeyse 'Kus әq ol әлец no人 . tseәлq

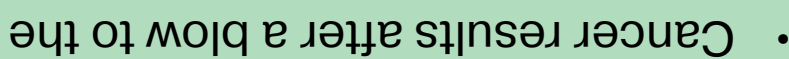
чұеәр оғ snoukuouks s! дәоиеЈ • sno!̣อ‡uoo s! ләоueว •

:suzku әsәчł Yunqәр of łuełsodu! S! ł!

sןeว!məuо u!eนəo of pəsodxə бu!əq pue bu!yous sәбеләләq ग!ןочоэе бu!unsuoว• әsnedouəu ләңرe Кł!sәqo

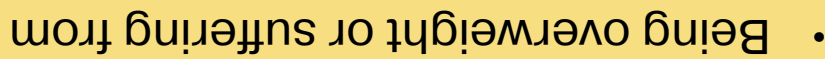

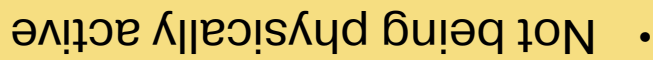

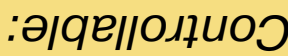

(sı!!d әм!ฺdәэеџиนоว)

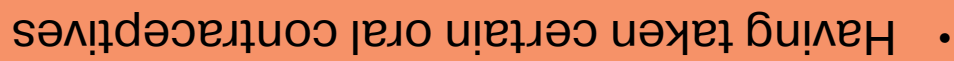
sıeәк

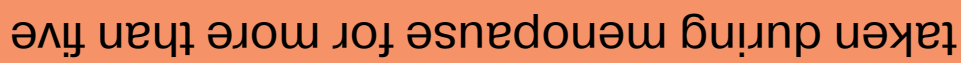

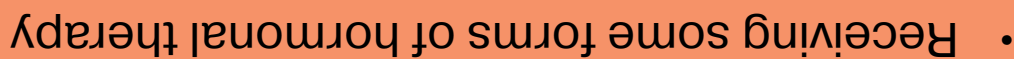
әวиәэรә|оре

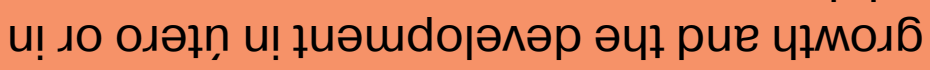
бu!ınp $\Lambda_{\|}$!̣ рәняеәлq

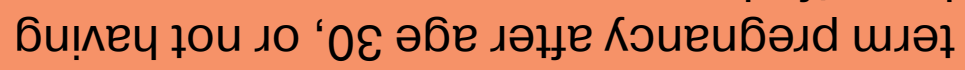
- In

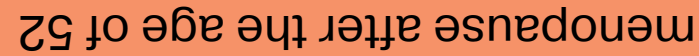

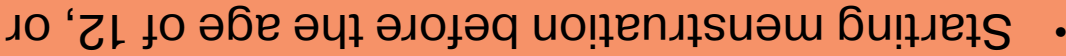
ләоиео ие!ाело до ұseәлq

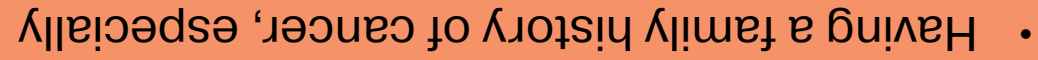

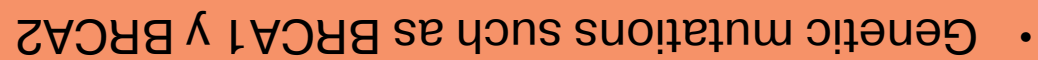
6u!6r •

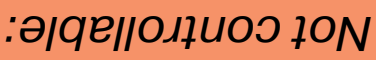
:ләоие łseәлq

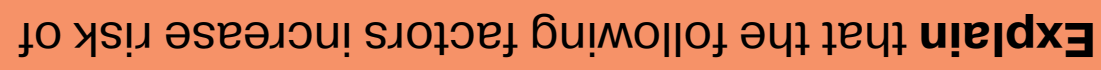

ןenuew dəoueo 7seәлg әчұ 10 I ләңdeч० оғ ләјәу

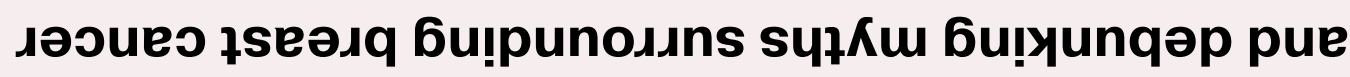
¿기 7e s! 04M 


\section{Who is at risk?}

\section{and debunking myths surrounding breast cancer}

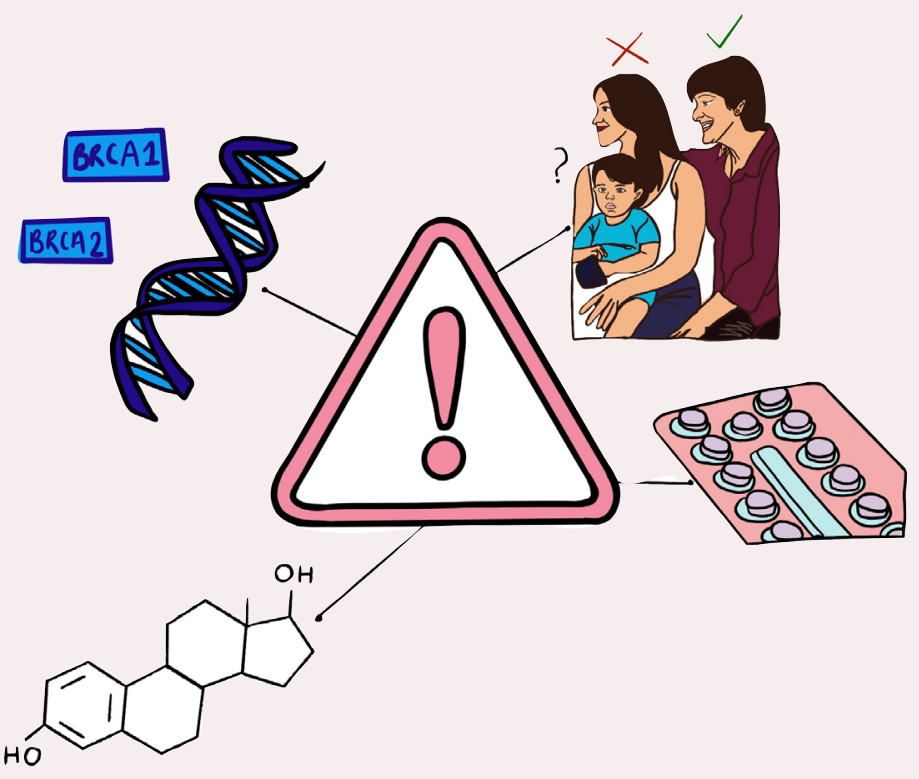

\section{Controllable factors that increase the risk}

of breast cancer

- Not being physically active

- Being overweight or suffering from obesity after menopause

- Consuming alcoholic beverages

- Smoking and being exposed to certain chemicals

\section{Examples of factors increase risk of breast} cancer:

- Aging

- Genetic mutations such as BRCA1 y BRCA2

- Having a family history of cancer, especially breast or ovarian cancer

- Never having had a pregnancy, having a fullterm pregnancy after the age of 30 , or not having breastfed

- Having taken certain oral contraceptives (contraceptive pills)

\section{Myths}

- Cancer is contagious

- Cancer is synonymous to death

- Cancer results after a blow to the breast

- You have to be shy, ashamed or afraid to examine yourself or have a diagnosis of cancer

- Cancer results from having very small or very large breasts 


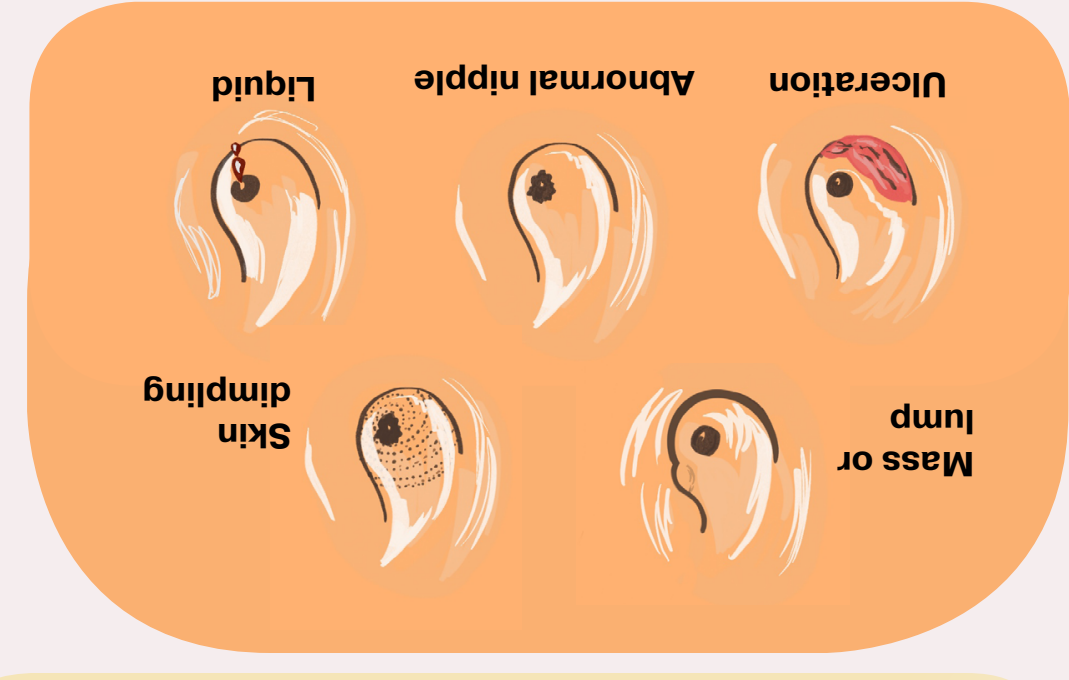

•әблечวง!p 10

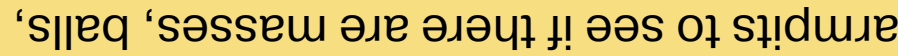

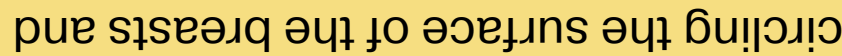
рuеч ләчұо әчғ рue реәч әчұ рu!чәq

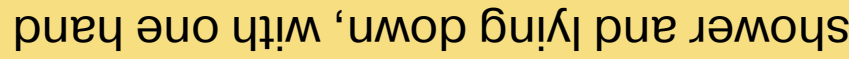

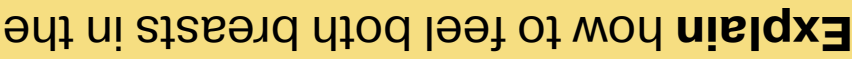

'ssəuybnoג/sә|yu!ıM

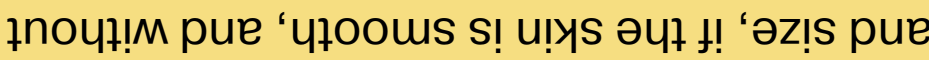

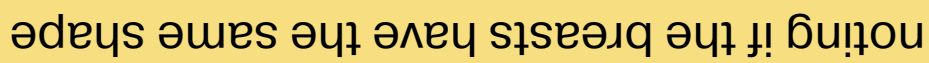

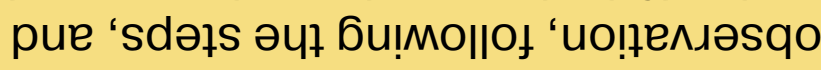

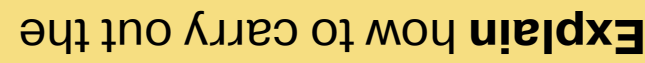

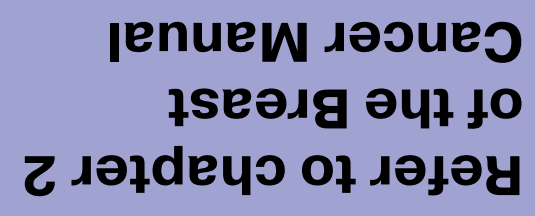

łsеәлq әчұ 10

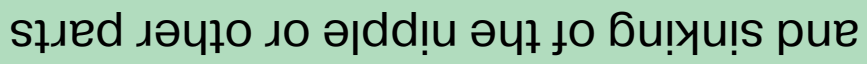

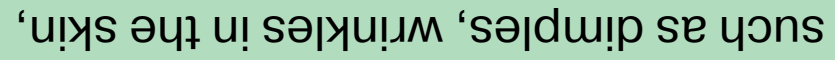

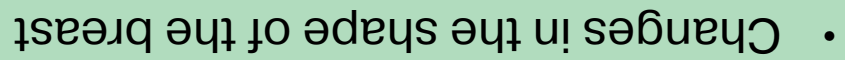

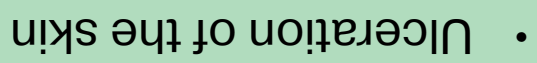

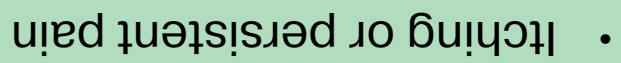
ssәuрәл до чұшлем 'Би!||әмS •

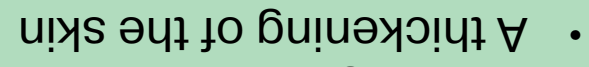
t! moı p!n t to әблецоร!

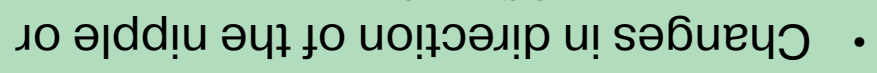

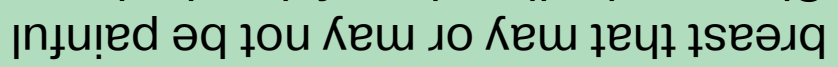

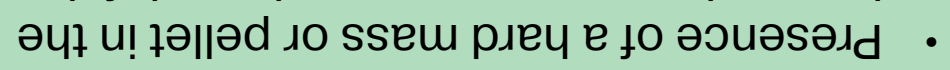

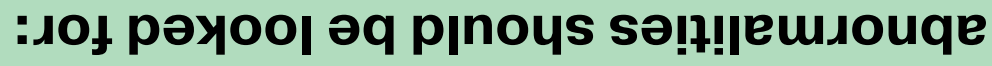

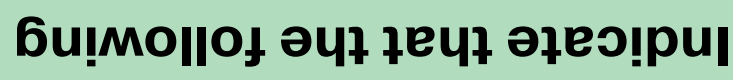

\section{$\varepsilon$}

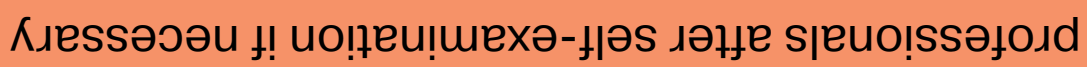

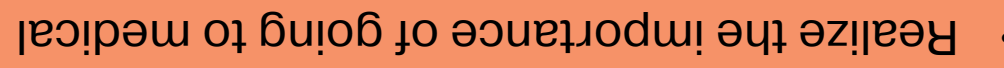
stseәлq

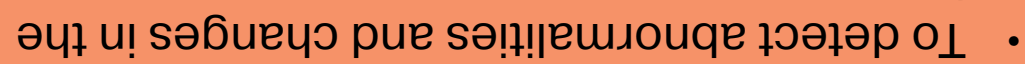

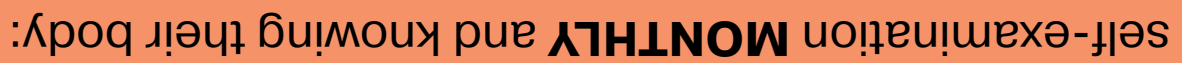

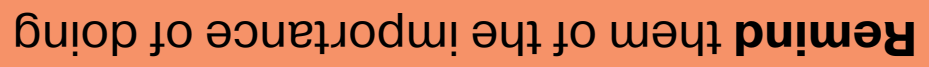
$\boldsymbol{\tau}$

\section{¿әu!q U! dooueo} 7Seәлq 70ә7әр әм uеo MOH 


\section{How can we detect breast cancer in time?}

Why is it important to know your body and do self-examination?

- To detect abnormalities and changes in the breasts

- Realize the importance of going to medical professionals due to self-examination

\section{DO MONTHLY SELF- EXAMINATIONS}

What to look for:

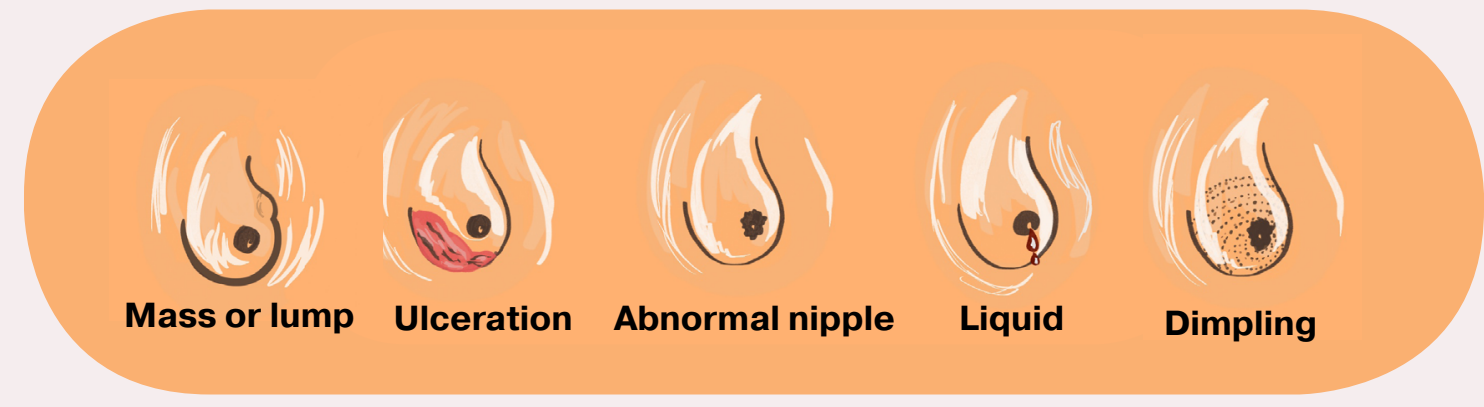

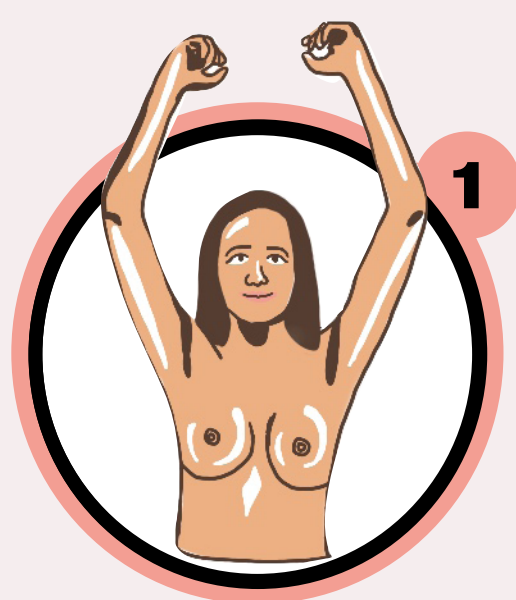

Changes or difference between the breasts

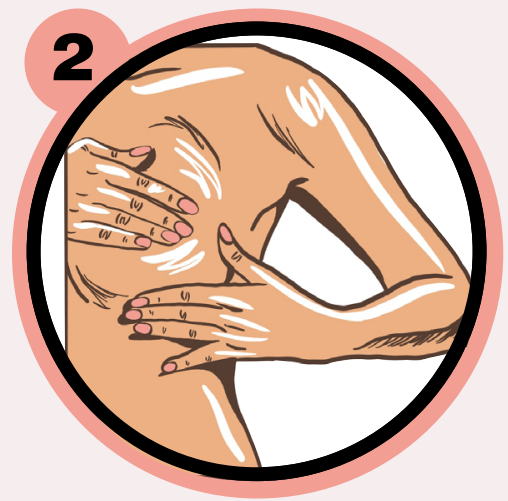

Circular movements

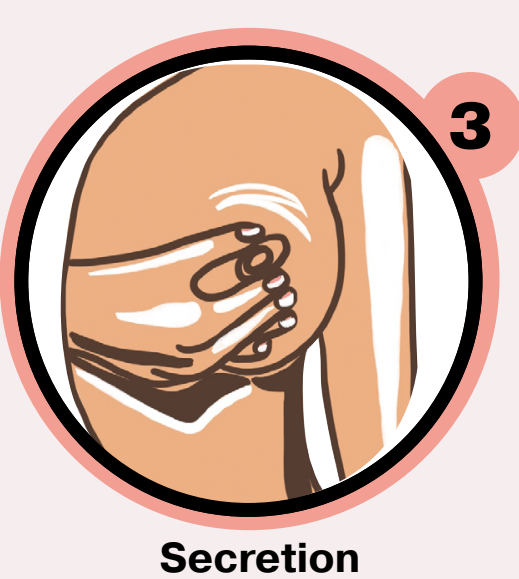

Ulceration or mass in the axilla

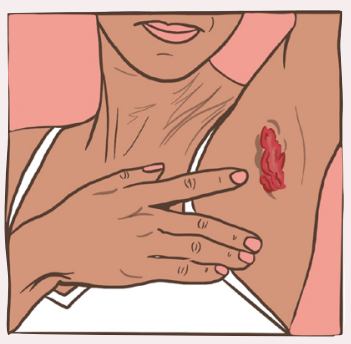


s suexә fo suo!ıeł!u!! pue słyəuәq

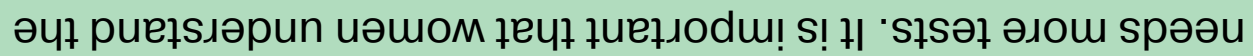

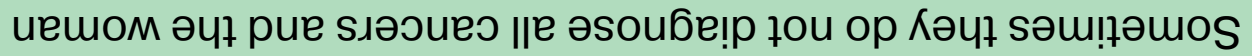

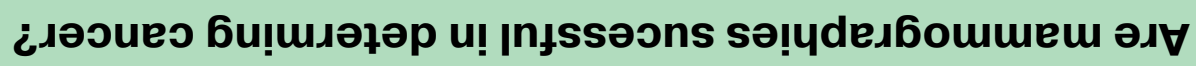

'słuәшіsn!pe әуеш иео

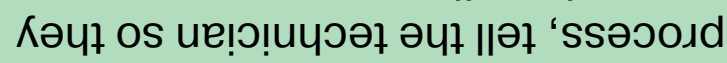

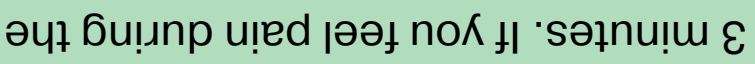

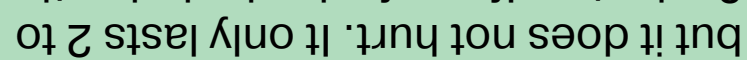
'bu!̣ouue әq ueo Кydeıbommew $\forall$ ¿łuny sə̣ydeıboumeu og suo!łsenb uowmoo

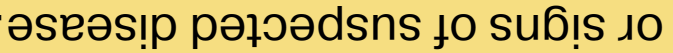

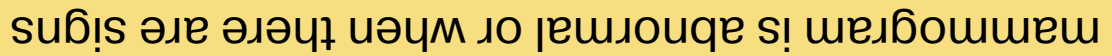

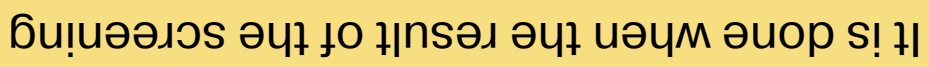
Kydes6ommeu ग!łsoube! ' 2

sןeuo!ssəjoıd jeэ!pəu кq рәи!шләғәр әбе лә!леә ие ұе suелбошшеш jenuue ł

әбe to sıeəর ot łe бu! uu! бәq

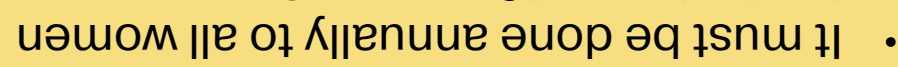
रł!ןemsouqe to smołduks

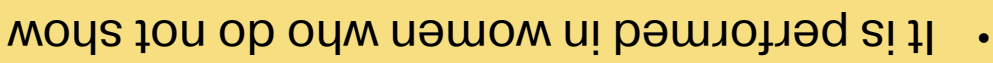

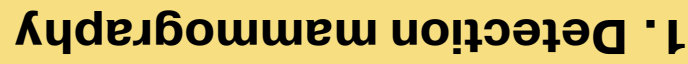
'Kydesboumeu

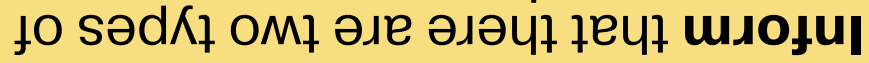
Kydes6oumew 


\section{Detection}

\section{Clinical Exam}

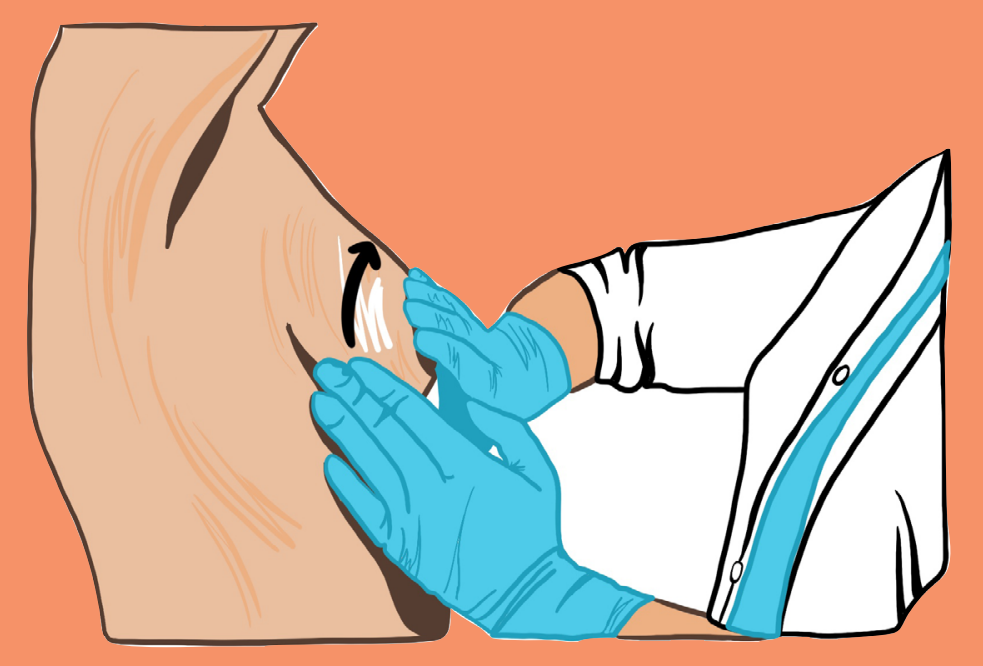

- 25 years of age

- annual

\section{Mammography}

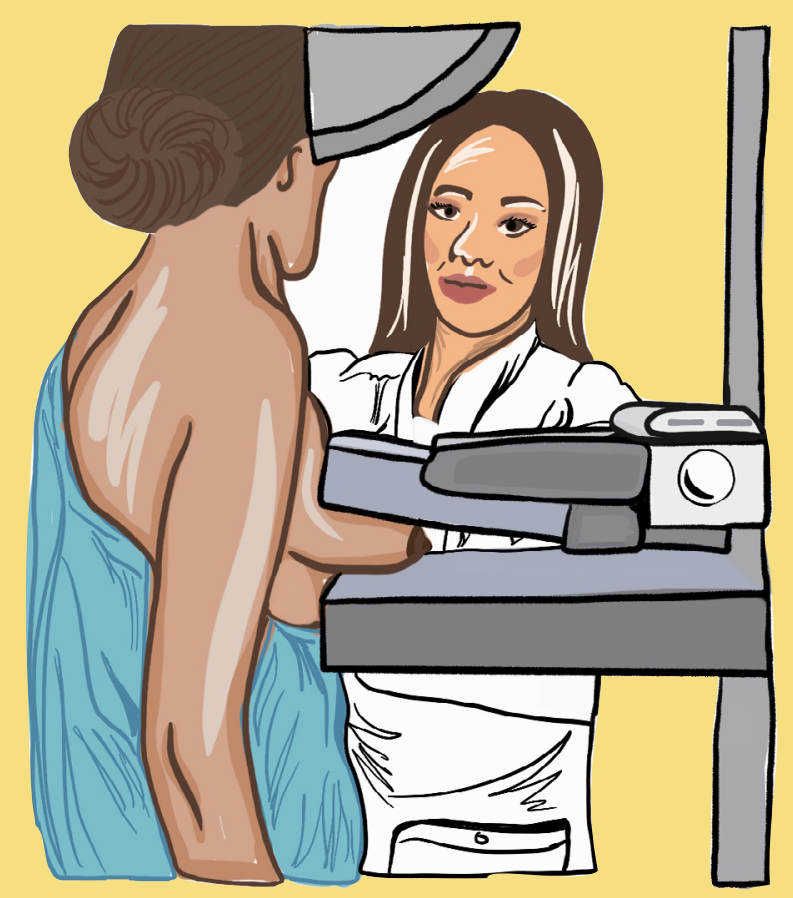

- annual

- 40 years of age or before in case of high risk 


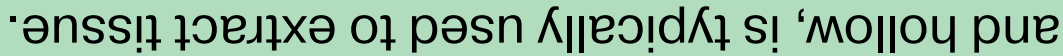

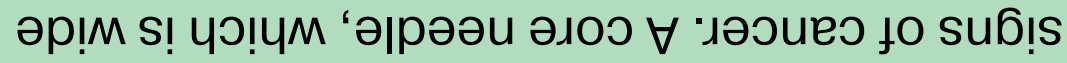

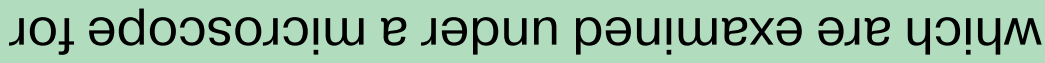

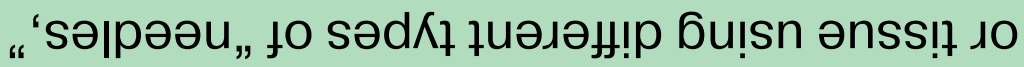

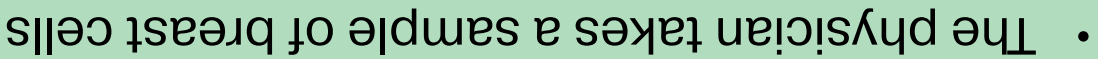

:s! Ksdo!q e ґечм u!ejdxヨ Ksdo!̣

- ріо sıeәк ов ıәрun әле ло sseu łseәлq е әлеч 'słseәлq әsиәр әлеч очм иәшом u! pәsn Кјәр!м S! ł • 'रydeıbommem

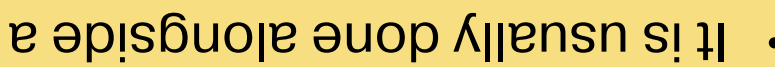

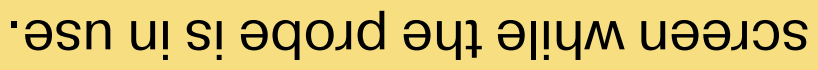

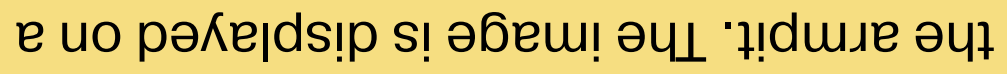

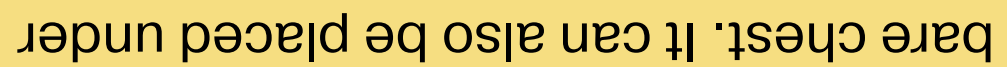
ıno $\alpha$ uo pәэеןd s! әqoıd $\forall$ 'sәбеш! әуеш ol sәлем punos səsn punosexpn u $\forall$ •

:s! punoseıןn ue ұечм u!ejdx punosediln ןenuew jəoueว 7seәлg әч7 10 † ләңdечо от ләјәу

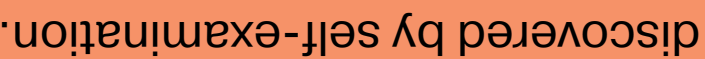

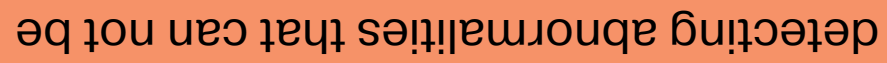
sмоाাе pue 'әл! senu! łou s! 'u!ed әsneo łou sәор ґечұ әлnрәэолd e s! Кydeıбommeu $\forall$

'pәuлодләd osןe s! punosexłן ue uәно

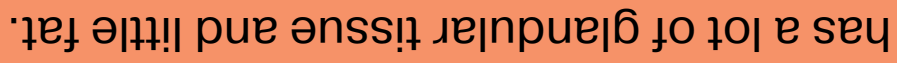

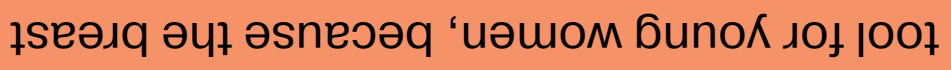

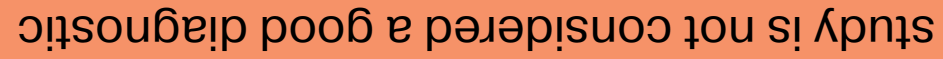

s!чł ұечł pu!m u! леәq ol ұuełлodm! s! łl

uo!ıeu!mexə

łseəıq jeo!u!

e u! рәјэәнәр әле sә!!!

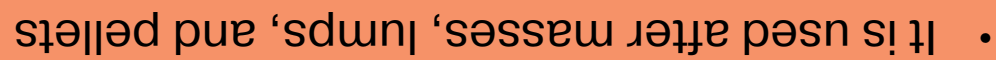

:s! Kydesboumem ग!łsoube!p е łечм u!eןdx

Кydes6oumew o!łsoube! 


\section{Diagnosis}

\section{Ultrasound}

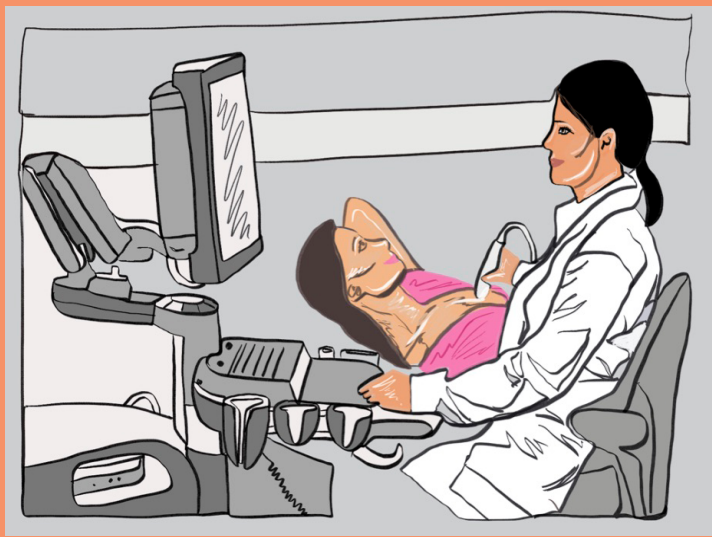

\section{Diagnostic Mammography}

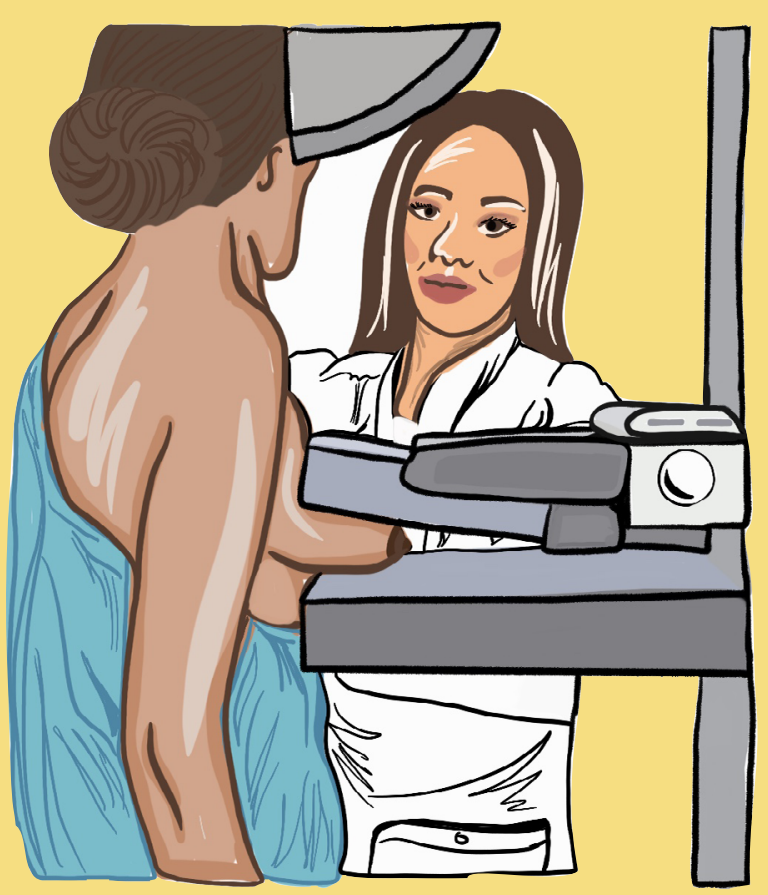

\section{Biopsy}

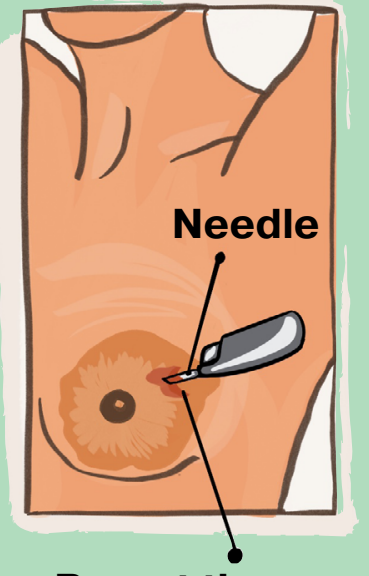

Breast tissue 
sıорdәวәл

әиоmı⿰丿 se yons sıәулеш

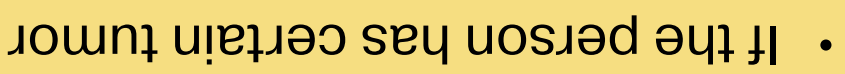
ләวиео

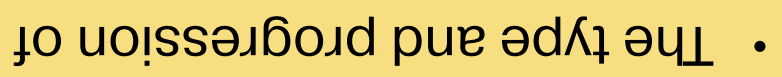
:se yons

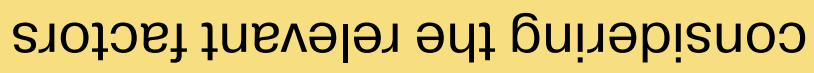
ләңе рәл!nbәл s! ұечм sәu!шıәюәр

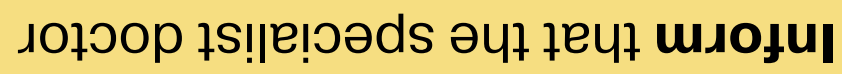

$\boldsymbol{Z}$

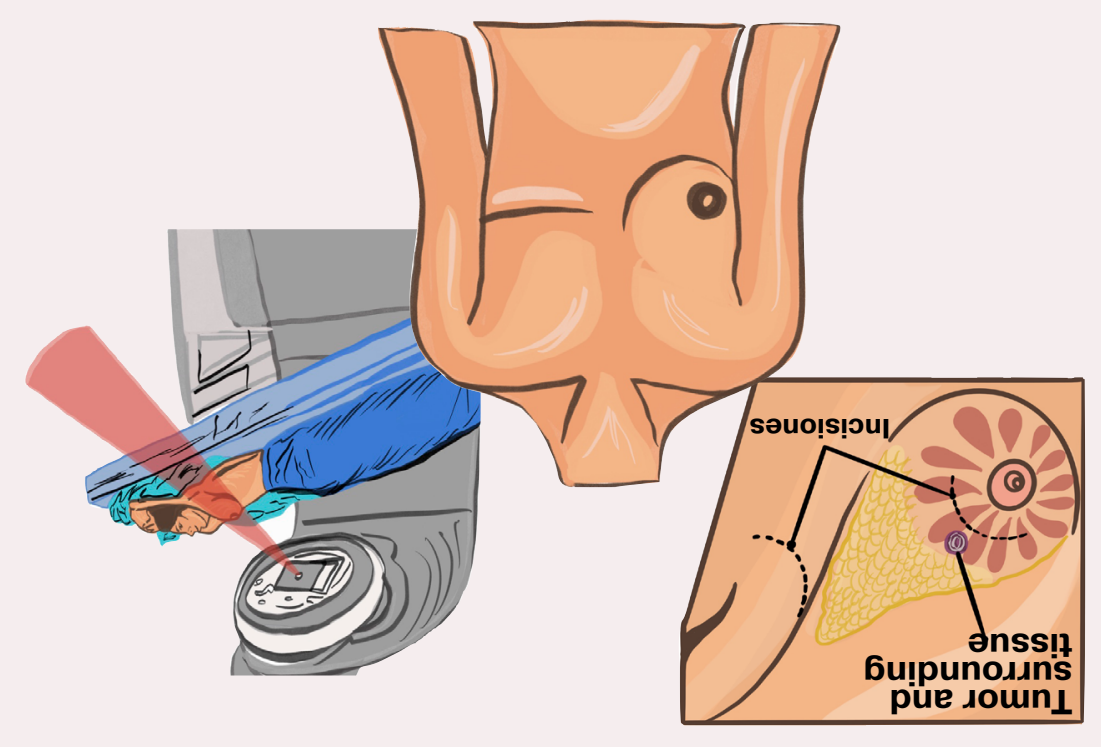

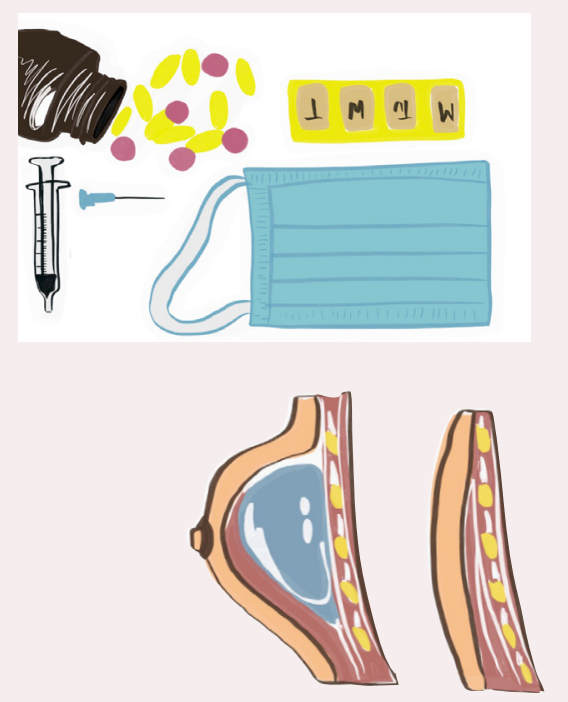

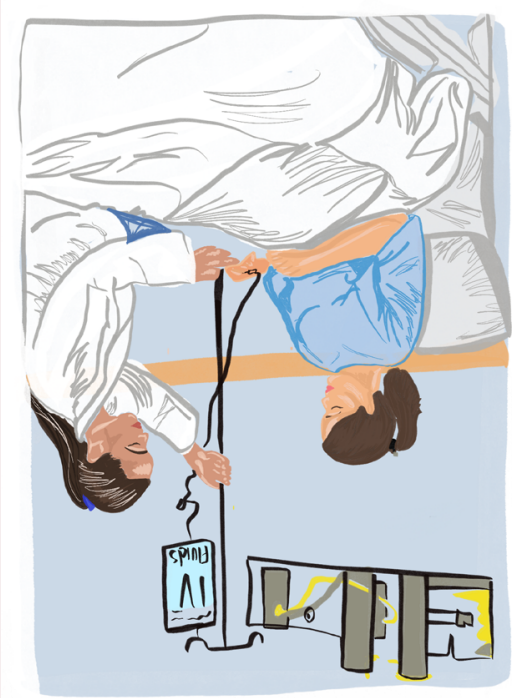

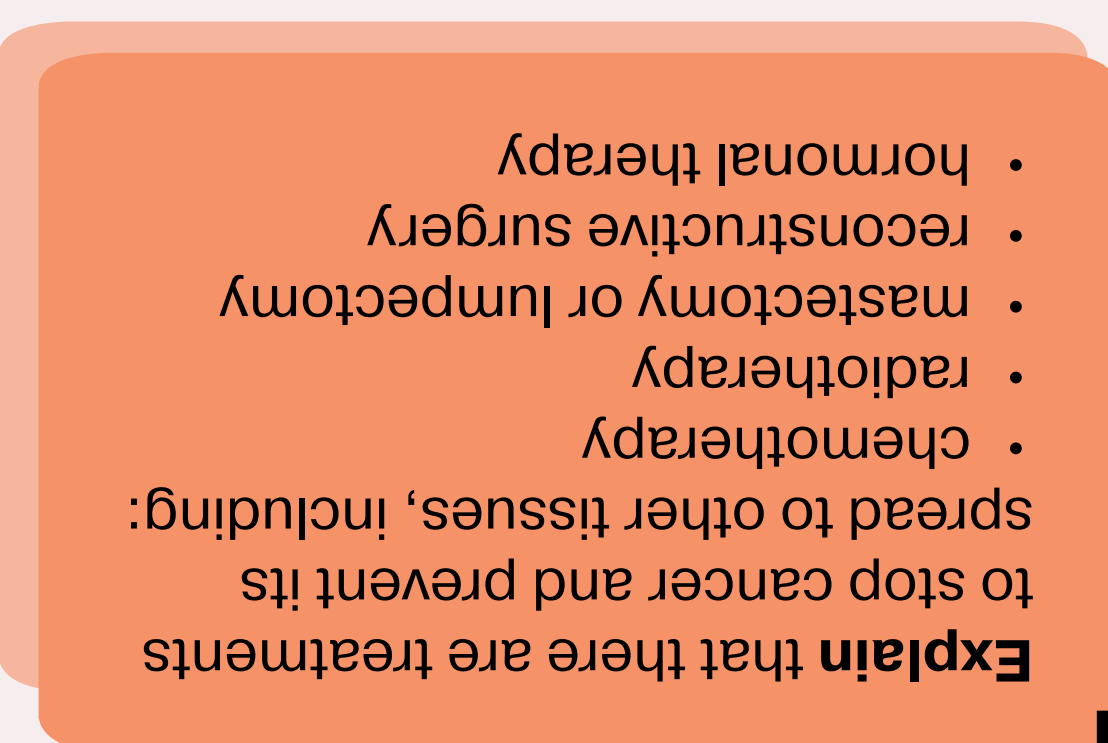

ןenueW Jә0ueว 7seәлg әчң to † ләңdеч० оң ләرәу 


\section{Treatment}

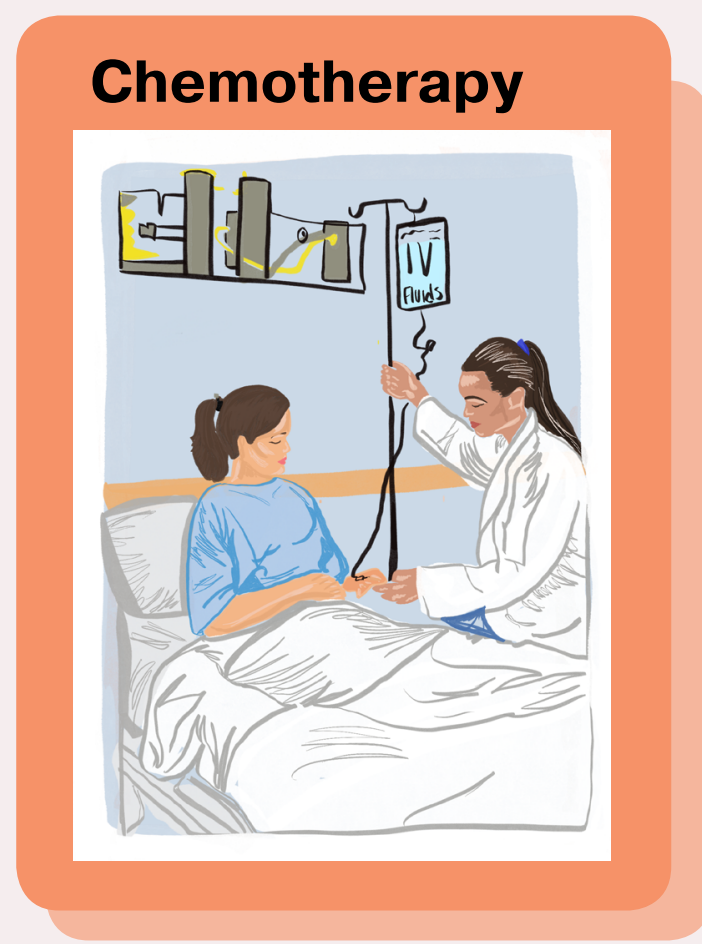

\section{Hormonal therapy}

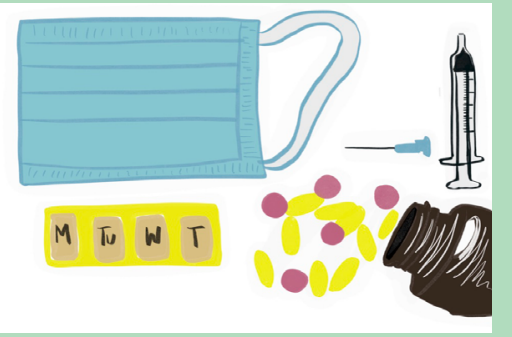

\section{Radiotherapy}

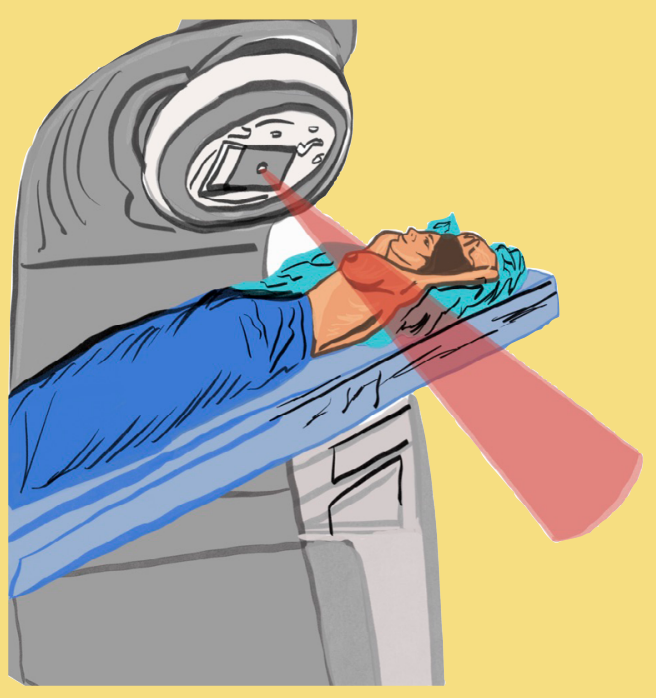

Reconstructive surgery

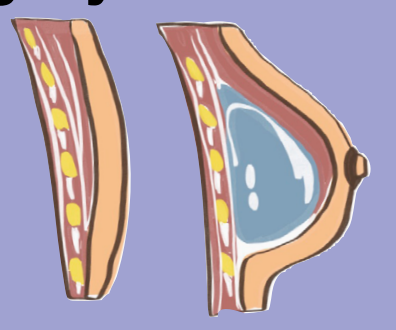

\section{Mastectomy or} lumpectomy

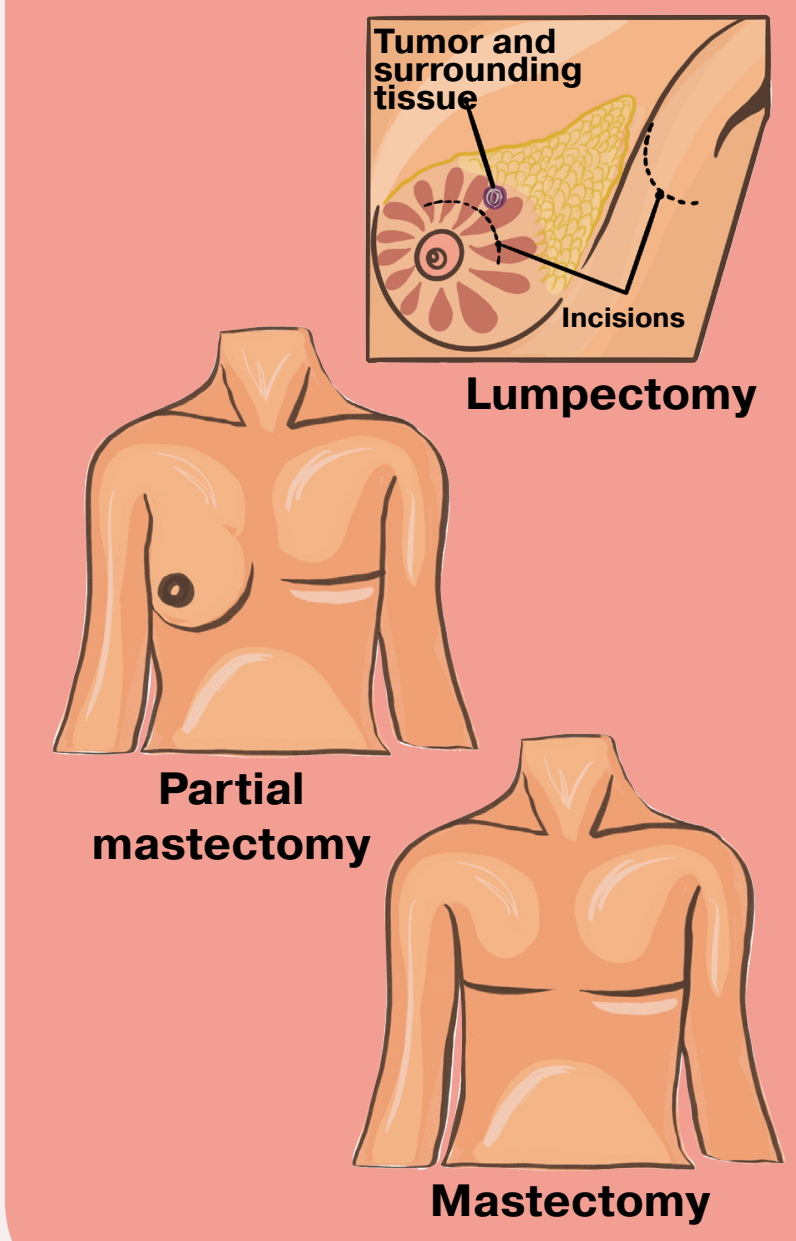




\section{ןenuew

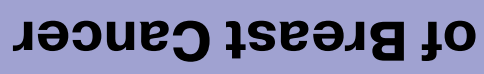 G ләғdечว ор ләјәу}

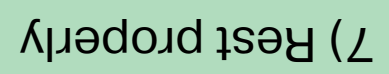

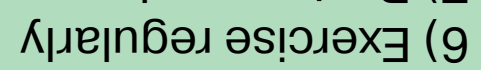

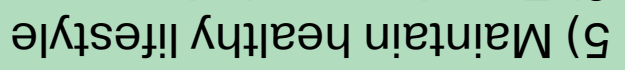

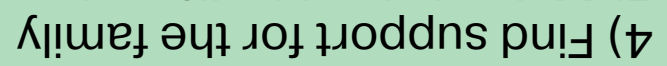

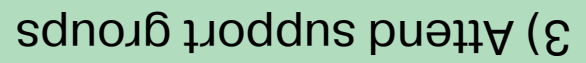

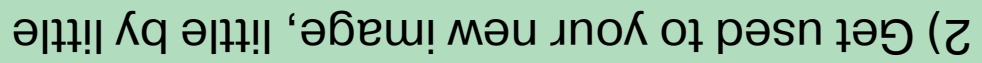

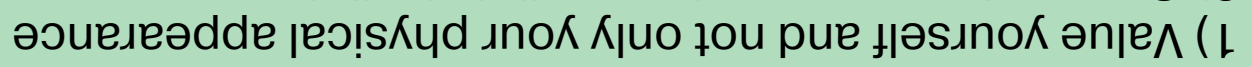

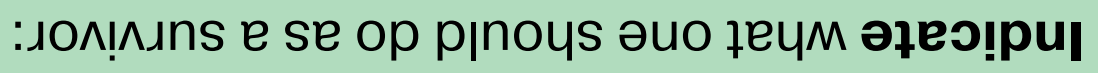

s!!eu әчұ u! sәбиечว • u!ys әчұ u! sәбueyว •

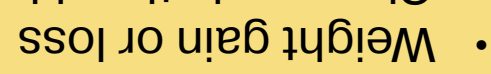

sieos -

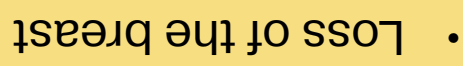
:ұuәшұеәл

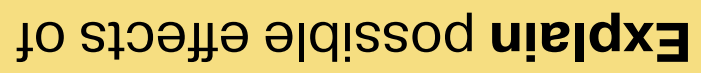

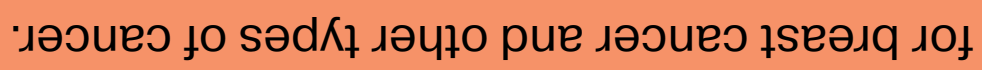

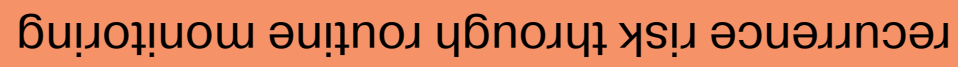
fo uo!̣ez!̣!!u!u әцł pue suołdmks

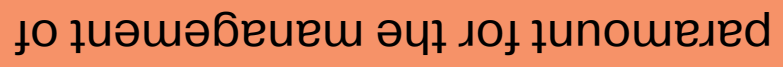

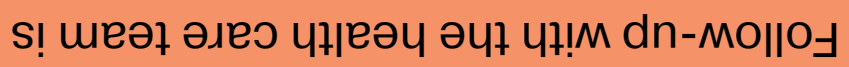

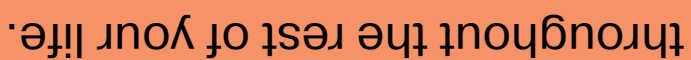
pue 'quәшіеәя ләңе Крәеррәшш! pue 6u!̣np 's!soube!̣ łо ұиәшош әцұ سол

:Jon!njns

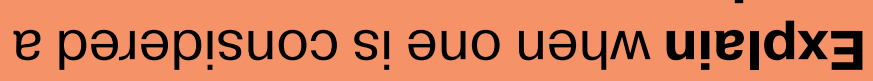

\section{d!ysjon!ndns pue quouqeodq-750d}




\section{Post-treatment and survivorship}

Possible effects of treatment:

- Loss of the breast

- Scars

- Weight gain or loss

- Changes in the skin

- Changes in the nails

- Hair loss

\section{What is a survivor?}

An individual is a cancer survivor from the moment of diagnosis, during and

immediately after treatment, and throughout

the rest of their life.

\section{As a survivor, it is important to:}

1) Value yourself and not only your physical appearance

2) Get used to your new image, little by little

3) Attend support groups

4) Find support for the family

5) Maintain healthy lifestyle

6) Exercise regularly

7) Rest properly

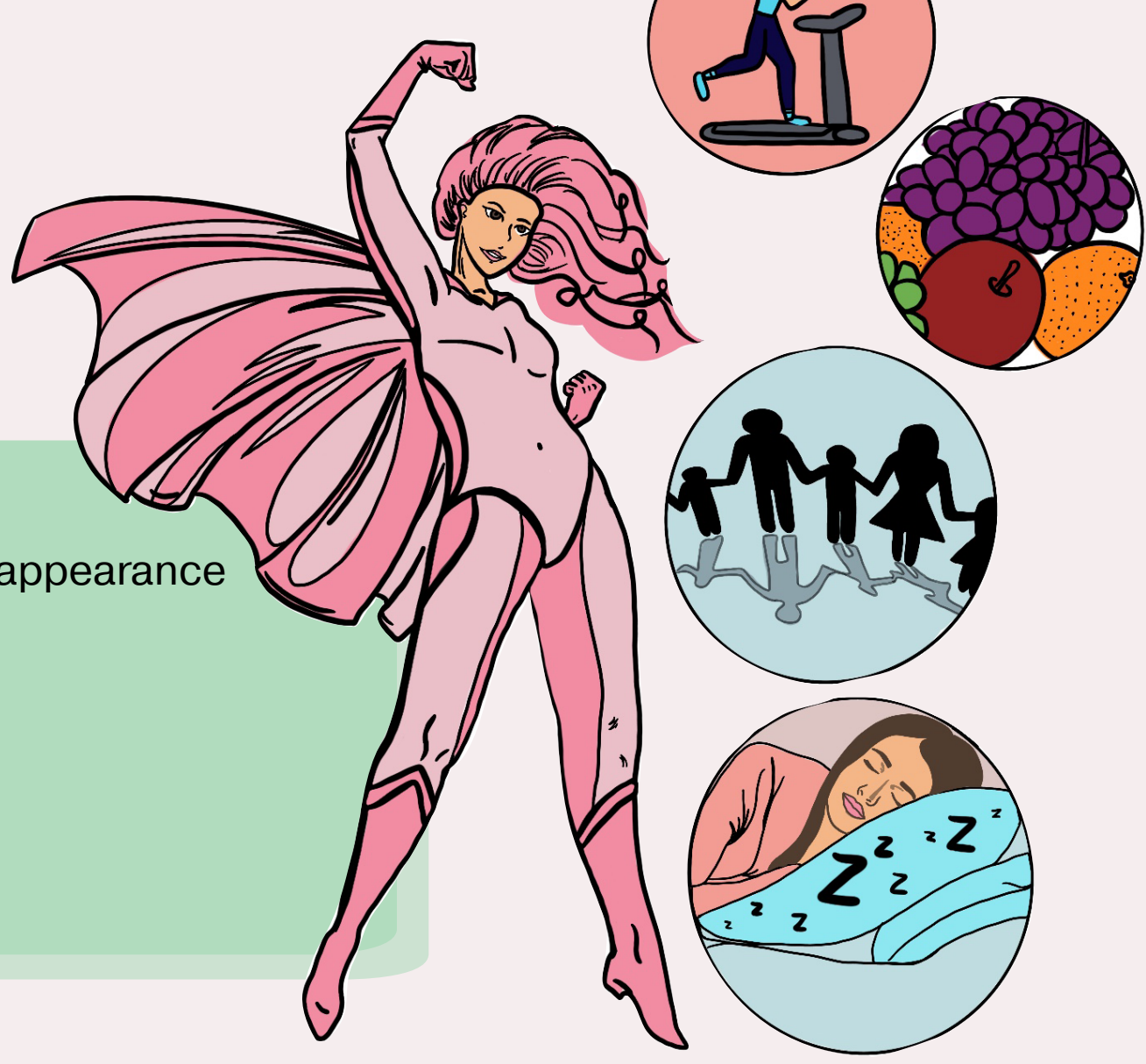


